\title{
IMPLEMENTASI GOOGLE MY BUSINESS (GMB) DALAM PROMOSI PARIWISATA DI KOTA KUPANG DAN SEKITARNYA
}

\author{
Gerlan A. Manu ${ }^{1}$, Diana Fallo² \\ ${ }^{1}$ Universitas Citra Bangsa, Prop Nusa Tenggara Timur \\ ${ }^{2}$ Universitas Citra Bangsa, Prop Nusa Tenggara Timur \\ ${ }^{1}$ gerlan.manu@gmail.com, ${ }^{2}$ dianayani25@gmail.com
}

\begin{abstract}
ABSTRAK
Sektor pariwisata di Indonesia menjadi salah satu keunggulan ekonomi Indonesia. Berdasarkan Laporan Kinerja Kementerian Pariwisata Tahun 2016, salah satu masalah utama dalam pertumbuhan kepariwisataan di Indonesia adalah belum optimalnya pemanfaatan kemajuan Teknologi Informasi dan Komunikasi dalam mempromosikan destinasi pariwisata secara nasional maupun internasional. Kota Kupang adalah Ibukota Provinsi Nusa Tenggara Timur, yang memiliki beragam potensi wisata baik itu wisata alam, wisata kuliner, wisata budaya dan wisata rohani. Dengan pemanfaatan TIK maka kegiatan promosi pariwisata di Kota Kupang dapat dilakukan dengan efektif dan efisien. Informasi pariwisata di Kota Kupang menggunakan website resmi pemerintah daerah, dinilai tidak terstuktur, tidak terperinci dan tidak terbaharui. Pemanfaatan TIK dalam pengembangan promosi pariwisata di Kota Kupang dan sekitarnya dapat menggunakan Google My Business (GMB). GMB merupakan sebuah platform bisnis yang disediakan oleh Perusahaan Google secara online, bersifat gratis, cepat, dan mudah digunakan oleh suatu organisasi atau perusahaan dalam mempromosikan tempat bisnis, brand atau produk. GMB terintegrasi secara langsung dengan Google Map, sehingga mempermudah wisatawan untuk menemukan suatu objek wisata. Selain itu GMB menyediakan interaksi antara pengelola bisnis (pengelola objek wisata) dan pelanggan (pengunjung wisata). Sehingga dari penelitian ini selain untuk mengetahui implementasi GMB dalam hal mempromosikan tempat wisata di Kota Kupang dan sekitarnya, juga dalam jangka panjang dapat meningkatkan promosi dan pelayanan wisata di Kota Kupang dan sekitarnya.
\end{abstract}

Kata Kunci : Google My Business, Promosi Pariwisata, Teknologi Informasi

\section{PENDAHULUAN}

Salah satu satu keunggulan perekonomian di Indonesia adalah sektor pariwisatanya. Sektor pariwisata akan terus dapat dieksplorasi dan dapat memberikan keuntungan bagi setiap proses bisnis yang terkait di dalamnya. Berdasarkan Laporan Akuntabilitas Kinerja Kementerian Pariwisata Tahun 2016, salah satu masalah utama yang menjadi kendala tumbuhnya kepariwisataan di Indonesia adalah belum optimalnya pemanfaatan kemajuan teknologi informasi dan komunikasi dalam mempromosikan destinasi pariwisata secara nasional maupun internasional [4]. Hal ini dikarenakan masih terbatasnya kesadaran dan kemampuan setiap pihak yang terkait dalam pariwisata untuk memanfaatkan kemajuan teknologi informasi tersebut dalam rangka pengembangan promosi pariwisata di Indonesia.

Kota Kupang adalah Ibukota Provinsi Nusa Tenggara Timur, yang memiliki 
beragam potensi wisata baik itu wisata alam, wisata kuliner, wisata budaya, wisata sejarah dan wisata rohani. Tempat wisata yang ada di Kota Kupang dan sekitarnya dikelola oleh Pemerintah Daerah dan juga Swasta. Usaha pemerintah daerah dalam pengembangan promosi pariwisata di Kota Kupang dan sekitarnya adalah melalui informasi wisata di website resmi pemerintah daerah, dan melalui media katalog wisata yang disebarkan di berbagai tempat.

Pemanfaatan Teknologi Informasi dan Komunikasi dalam pengembangan promosi pariwisata di Kota Kupang dan sekitarnya dapat menggunakan Google My Business (GMB). GMB merupakan sebuah platform bisnis yang disediakan oleh Perusahaan Google secara online, dapat digunakan secara gratis, cepat, mudah oleh suatu organisasi atau perusahaan dalam mempromosikan tempat bisnisnya, mempromosikan brand atau produk perusahaan. Dengan GMB dapat mempermudah pencarian informasi bisnis (dalam hal ini objek/tempat wisata) oleh masyarakat luas, dan dapat terjangkau secara nasional maupun internasional, karena GMB terintegrasi secara langsung dengan seluruh aplikasi Google. Berdasarkan data dari www.fivestarreviewssite.com terdapat $77 \%$ trafik pencarian di Internet ditangani oleh Google dengan 3.5 Milyar pencarian per hari, dan 1.2 Triliun pencarian per tahun di seluruh dunia [3].

Dalam penelitian ini akan dibahas tentang implementasi GMB dalam pengembangan promosi pariwisata di Kota Kupang dan sekitarnya. Penelitian ini menggunakan Analisis SWOT untuk menganalisa pemanfaatan GMB dalam mempromosikan tempat wisata di Kota
Kupang dan sekitarnya. Sehingga pada akhirnya pengelola tempat wisata atau objek wisata baik itu Pemerintah atau Swasta dapat mengetahui pemanfataan TIK dengan menggunakan GMB dan dapat menentukan strategi pemasaran untuk meningkatkan promosi dan pelayanan pada tempat wisata atau objek wisata yang dikelolanya.

\section{METODE PENELITIAN}

Penelitian ini akan dilaksanakan selama 9 bulan, yaitu Maret hingga Nopember 2019. Pelaksanaan penelitian ini dilakukan pada tempat wisata yang ada di Kota Kupang dan sekitarnya. Tahapan penelitian dalam penelitian ini dapat dilihat pada diagram alir berikut :

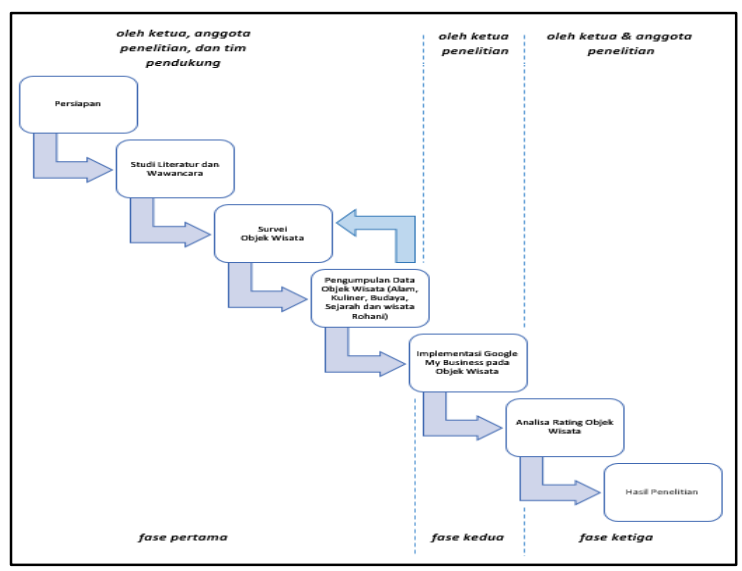

Gambar 1. Tahapan Penelitian

Metode penelitian yang digunakan dalam penelitian ini adalah menggunakan gabungan metode kualitatif dan kuantitatif. Dalam pendekatan kualitatif akan dilakukan pengamatan, wawancara dan dokumentasi tentang objek wisata yang ada di Kota Kupang dan sekitarnya. Melalui pendekatan kualitatif ini diperoleh opini wisatawan terhadap suatu objek wisata di Kota Kupang dan sekitarnya. Sedangkan dengan pendekatan kuantitatif akan diperoleh tingkat atau rating objek wisata 
oleh pengunjung pada objek wisata di Kota Kupang dan sekitarnya. Tingkat atau rating objek wisata ini diperoleh dengan mengimplementasikan Google My Business. Selanjutnya hasil pengamatan dari implementasi GMB tersebut dianalisa dengan menggunakan Analisis SWOT.

\section{HASIL DAN PEMBAHASAN}

\section{Objek atau Tempat Wisata di Kota Kupang dan sekitarnya}

Sesuai dengan tahapan penelitian pada gambar 1 maka peneliti membentuk tim pendukung yang terdiri dari beberapa mahasiswa. Dibawah koordinasi peneliti, tim pendukung bertugas untuk melakukan survei awal dengan cara mengunjungi tempat/ objek wisata yang berada di sekitar Kota Kupang. Melakukan pengamatan terhadap jumlah pengunjung, fasilitas, lokasi, dan informasi pengelolaan objek wisata lainnya. Berdasarkan survey tim pendukung, terdapat 32 objek/ tempat wisata di Kota Kupang dan sekitarnya yang sering mendapat kunjungan dari para pengunjung wisata, yang dapat dilihat pada tabel 1 berikut.

Tabel 1. Objek/ Tempat Wisata di Kota Kupang dan sekitarnya.
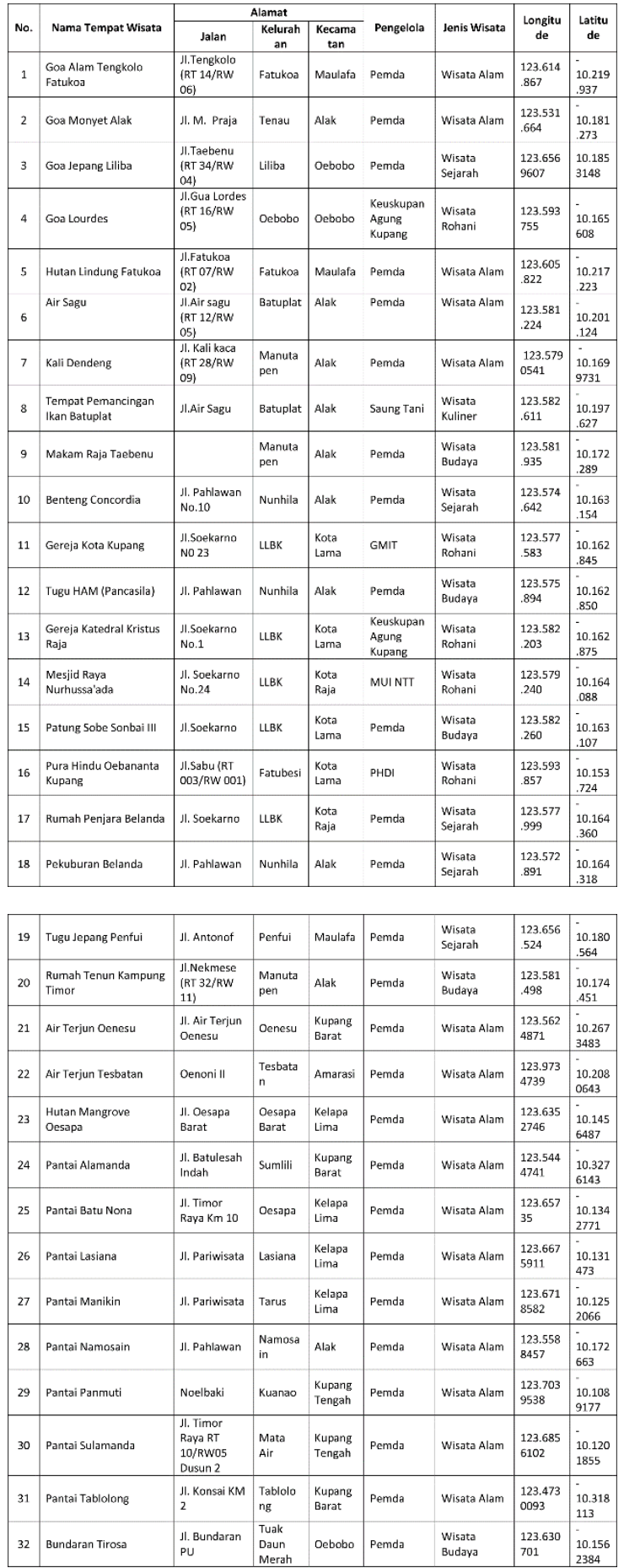

Terdapat beberapa objek Wisata di Kota Kupang dan sekitarnya yang sering dikunjungi pengunjung lengkap dengan beberapa fasilitas dan adapun beberapa diantaranya masih dalam pengembangan belum memiliki fasilitas yang memadai. 


\section{Penggunaan Teknologi dan Informasi dalam Promosi Pariwisata}

Kota Kupang memiliki objek wisata yang cukup memadai dengan beragam jenis seperti Wisata Alam, Wisata Budaya, Wisata Sejarah dan Wisata Kuliner. Pada umumnya promosi Objek Wisata tersebut dilakukan melalui pembicaraan masyarakat. Hal ini mengakibatkan informasi tentang Objek Wisata susah dijangkau oleh para pendatang atau turis. Hanya terdapat beberapa objek wisata saja yang diinformasikan di Website Resmi Pemerintah Kota Kupang www.kupangkota.go.id.

Promosi dan penyebaran informasi tentang Objek Wisata di Kota Kupang dan sekitarnya perlu dilakukan secara rutin dan dengan informasi terkini (up to date). Umumnya informasi objek wisata yang diperoleh di Website Resmi Pemerintah Kota Kupang bersifat statik, atau tidak berubah-ubah.

Menurut Rangkuti, Promosi adalah kegiatan penjualan dan pemasaran dalam rangka menginformasikan dan mendorong permintaan terhadap produk, jasa, dan ide dari perusahaan dengan cara mempengaruhi konsumen agar mau membeli produk dan jasa yang dihasilkan oleh perusahaan [2].

Salah satu teknik promosi pariwisata Kota Kupang yang dilakukan dalam penelitian Kasim, dkk adalah pembuatan media katalog wisata dan website dengan tampilan grafis yang menarik sehingga dapat menarik wisatawan untuk membacanya [1].

Penggunaan Teknologi dan Informasi mendukung teknik dan strategi promosi pariwisata agar menjadi lebih efisien dan efektif. Dari sisi wisatawan, penggunaan teknologi dan informasi mempermudah wisatawan dalam mencari informasi tentang suatu objek wisata. Seperti pada penelitian Zhara K dan Baiquni, diketahui aplikasi Google Maps dengan akses melalui smartphone menjadi pilihan paling banyak dari para wisatawan untuk mencari rute perjalanan, lokasi, dan informasi detail tentang suatu objek wisata, termasuk pengalaman wisatawan sebelumnya[6].

\section{Penggunaan Google My Business untuk Promosi Pariwisata}

Dalam penelitian ini peneliti menggunakan Google My Business (GMB) yang adalah sebuah platform gratis yang disediakan perusahaan Google kepada pemilik bisnis untuk memanajemen lokasi bisnisnya yang terintegrasi dengan Google Maps. Setiap pengusaha bisnis dapat melakukan pendaftaran bisnisnya secara gratis di Google My Business yang dapat diakses pada laman https://www.google.com/business

Keunggulan menggunakan Google My Business (GMB) adalah :

1. Dapat meningkatkan visibilitas suatu usaha bisnis tampil di Google Maps.

2. Dapat membantu peringkatan suatu usaha bisnis di Google Maps.

3. Memberikan informasi secara detail tentang suatu usaha bisnis untuk tampil di pencarian Google.

Google menggunakan informasi dari Google My Business sebagai basis data bisnis dan hal lain yang terkait dengan bisnis tersebut untuk menampilkannya dalam suatu hasil pencarian tertentu. Saat suatu daftar GMB baru dibuat atau suatu bisnis baru terdaftar pada GMB, maka secara terintegrasi label lokasi suatu bisnis akan tertera pada Google Maps.[5] 
Google My Business dapat diakses dengan dua platform berbasis web dan aplikasi mobile (Android/IOS). Setelah memiliki akun google, pengelola Objek Wisata dapat menambahkan lokasi pada Google My Business berupa objek wisata yang dikelolanya. Dalam penelitian ini, peneliti telah membuat akun gmail dengan nama "Wisata Kupang". Selanjutnya peneliti menambahkan lokasi bisnis pada Google My Business. Peneliti menambahkan lokasi sesuai dengan pengumpulan data yang diperoleh.

Berikut adalah langkah-langkah menambahkan lokasi pada Google My Business, sebagai berikut :

1. Buka laman https://business.google.com

2. Klik "tambahkan lokasi"

3. Masukan nama tempat wisata.

4. Masukan data alamat

5. Tandai lokasi pada peta google yang tersedia.

6. Pilih Kategori "Tujuan Wisata"

7. Masukan detail informasi nomor telepon yang dapat dihubungi, dan alamat situs jika ada.

8. Verifikasi Bisnis

Dari delapan langkah tersebut diatas yang perlu disiapkan terlebih dahulu adalah lokasi peta dari Tempat Wisata, dan nomor telepon untuk verifikasi. Pada langkah ke delapan, google melakukan verifikasi dengan cara mengirimkan kode verifikasi melalui sms ke nomor telepon yang dimasukkan. Pada lokasi tertentu verifikasi dilakukan dengan cara mengirimkan melalui pos untuk kode verifikasi ke alamat yang dimasukkan.

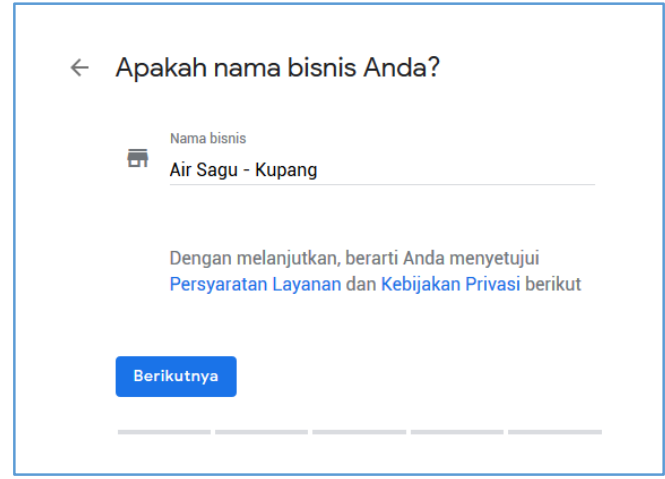

Gambar 2. Menambahkan Objek Wisata ke Google My Business

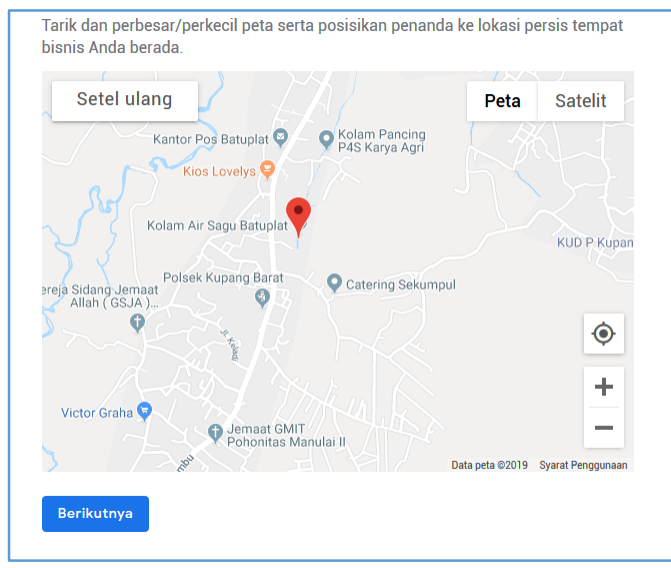

Gambar 3. Menambahkan Lokasi Peta Objek Wisata

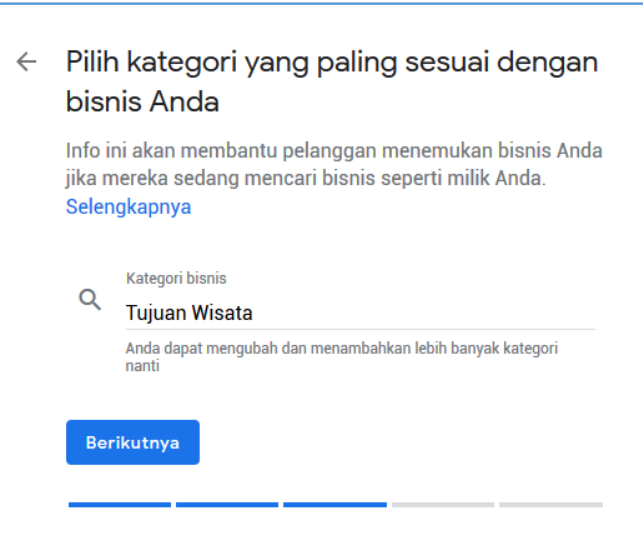

Gambar 4. Memilih Kategori "Tujuan Wisata" 


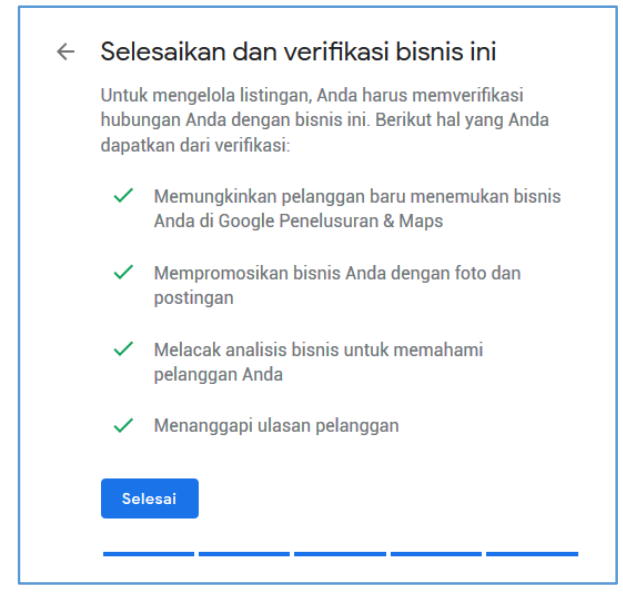

Gambar 5. Objek Wisata telah selesai ditambahkan di Google My Business

Dengan mengimplementasikan Google My Business sebagai alat untuk mempromosikan Objek Wisata secara gratis di Internet dapat dilakukan dengan mudah dan cepat. Berikut adalah statistik performa Objek Wisata Air Sagu yang telah ditambahkan di Google My Business selama 28 hari.

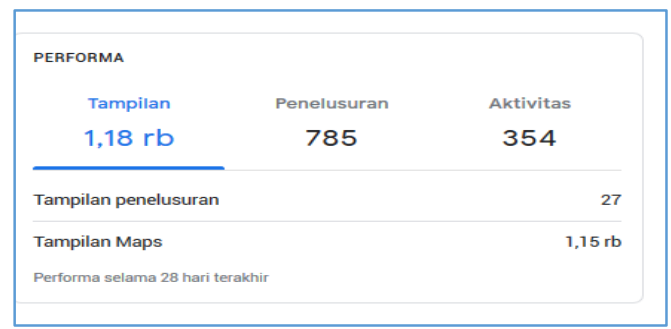

Gambar 6. Performa Objek Wisata Air Sagu berdasarkan GMB

Google My Business menyediakan fitur bagi pengunjung/ para wisatawan untuk juga dapat membagikan foto-foto, dan informasi lainnya melalui ulasan pengunjung terkait dengan Objek Wisata yang menjadi tujuan wisatanya. Dengan ini pengelola Objek Wisata dapat mengelola Objek Wisata dengan lebih terarah dan dapat meningkatkan pelayanan, terkait fasilitas dan kenyawaman Objek Wisata tersebut.

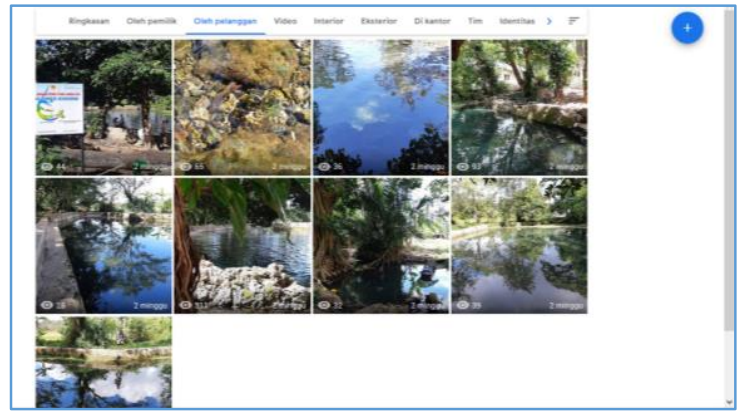

Gambar 7. Pengunjung Wisata menambahkan Foto Kunjungannya ke Objek Wisata Air Sagu - Kupang

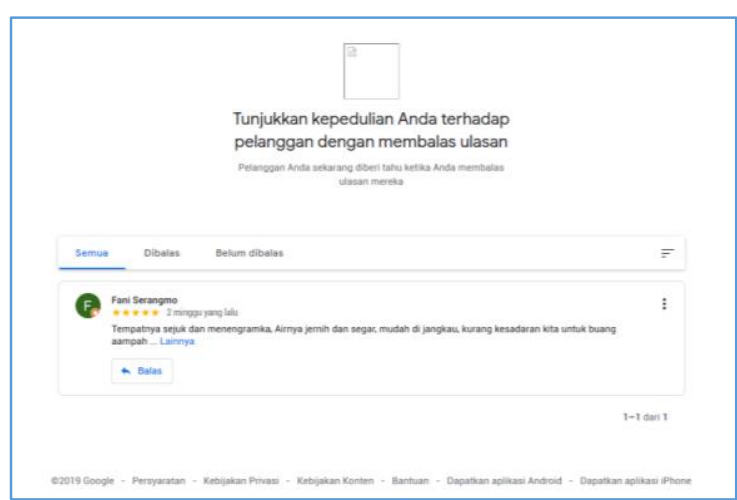

Gambar 8 Ulasan Pengunjung Wisata ke Objek Wisata Air Sagu - Kupang

Dapat dilihat pada gambar 8. diatas, pengunjung dapat memberikan ulasannya terkait dengan kunjungannya pada Objek Wisata Air Sagu - Kupang. Dengan ini pengelola Objek Wisata dapat langsung menjawab ulasan tersebut, agar dapat meningkatkan testimony pengunjung wisata pada Objek Wisata.

Selain itu dengan Google My Business pengelola Objek Wisata pun dapat dengan mudahnya membuat suatu situs/ website berisikan tentang informasi Objek Wisata, foto-foto Objek Wisata, dan ulasan para wisatawan. Situs Objek Wisata Air Sagu - Kupang dapat dilihat pada laman berikut https://airsagukupang.business.site 


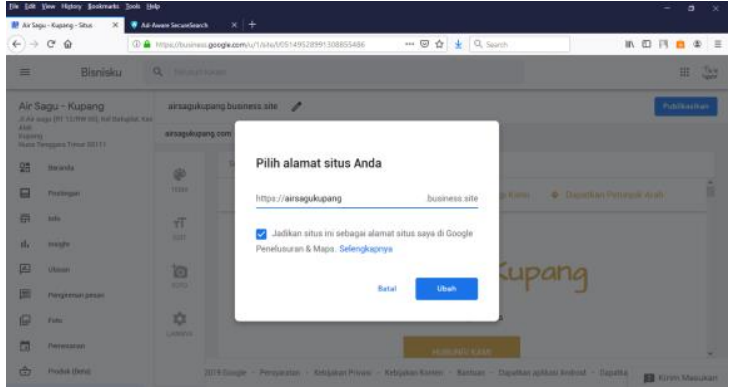

Gambar 9. Membuat situs/ website melalui Google My Business

\section{Analisis SWOT Implementasi Google My Business untuk Promosi Objek Wisata di Kota Kupang dan sekitarnya}

\section{Tabel 2. Analisis SWOT}

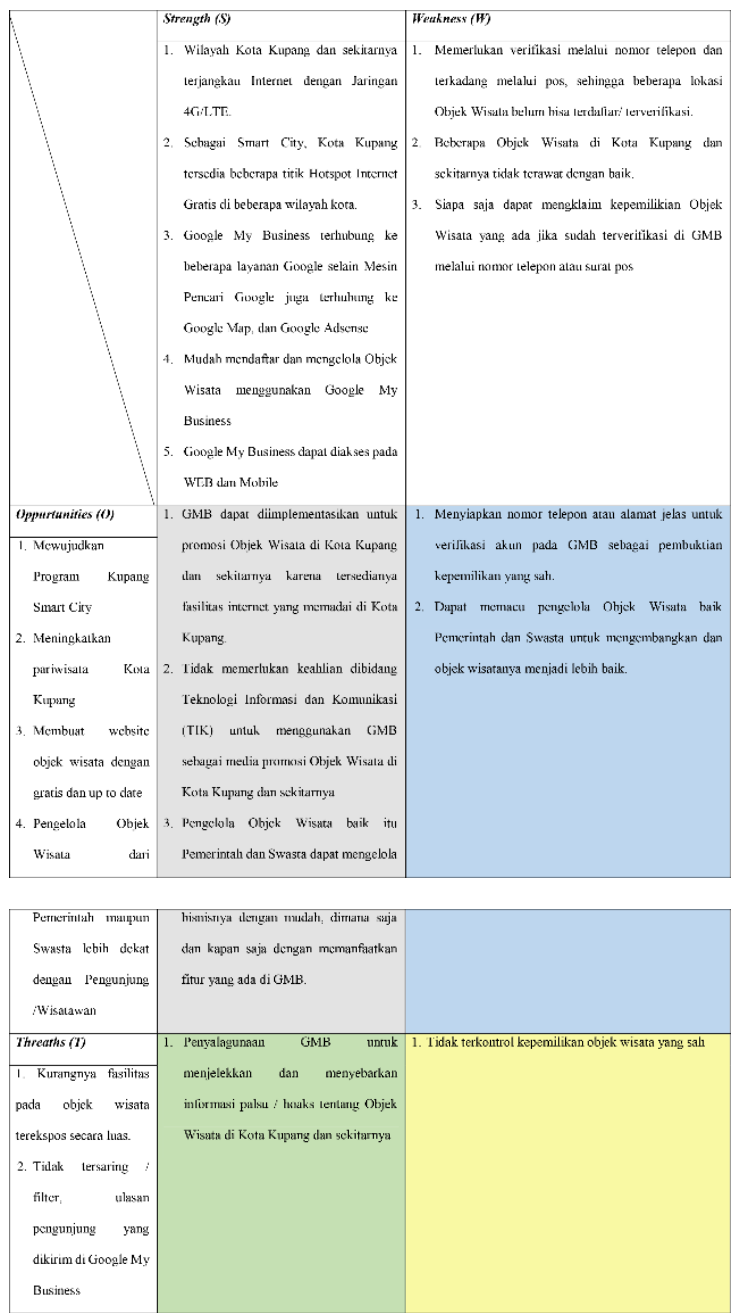

\section{KESIMPULAN}

Berdasarkan hasil penelitian yang dilakukan oleh peneliti, didapatkan simpulan Implementasi Google My Business untuk promosi Objek Wisata di Kota Kupang dan sekitarnya adalah sebagai berikut :

1. GMB dapat diimplementasikan untuk promosi Objek Wisata di Kota Kupang dan sekitarnya karena tersedianya fasilitas internet yang memadai di Kota Kupang.

2. Untuk menggunakan GMB sebagai media promosi Objek Wisata di Kota Kupang dan sekitarnya tidak memerlukan keahlian dibidang Teknologi Informasi dan Komunikasi (TIK).

3. Fitur yang ada di GMB dapat dimanfaatkan pengelola Objek Wisata baik itu Pemerintah dan Swasta dapat mengelola objek wisata dengan mudah dan memacuh mengembangkan objek wisata menjadi lebih baik.

4. GMB dapat disalahgunakan untuk menjelekkan dan menyebarkan informasi palsu / hoaks tentang Objek Wisata di Kota Kupang dan sekitarnya.

\section{DAFTAR PUSTAKA}

[1] A. Kasim, J. L. Bessie, dan A. E. Nyoko, "Strategi Promosi Pariwisata Kota Kupang melalui Pembuatan Media Katalog Wisata," Journal of Management (SME's), vol. 4 No.1, 2017

[2] Freddy Rangkuti, Strategi Promosi yang Kreatif dan Analisis Kasus Integrated Marketing Communication. Jakarta: PT Gramedia Pustaka Utama, 2009. 
Jurnal Pendidikan Teknologi Informasi (JUKANTI) Volume (2) No (2) Nopember 2019 e-ISSN : 2621-1467

[3] "Google My Business Facts - Five Star Reviews."

https://www.fivestarreviewssite.com/

wp-

content/uploads/2017/10/Research-

Project.pdf diakses tanggal 01

Agustus 2018

[4] Kementrian Pariwisata Republik

Indonesia. (2016). Laporan

Akuntabilitas Kinerja Kementrian

Pariwisata Tahun 2016.

www.kemenpar.go.id

[5] S. Hollingsworth, "How to Completely Optimize Your Google My Business Listing," Search Engine Journal (SEJ), 2017.

[6] Zhara K Malinda dan M. Baiquni, "Pengalaman Berwisata Menggunakan Google Maps Di Destinasi Pariwisata Yogyakarta", Jurnal Bumi Indonesia, vol. 6 No. 3, 2017 